\title{
Pasture establishment on non-cultivable hill country: a review of the New Zealand literature
}

\author{
K.N. TOZER ${ }^{1}$ and G.B. DOUGLAS ${ }^{2}$ \\ ${ }^{1}$ AgResearch Ruakura, Private Bag 3123, Hamilton, New Zealand 3214 \\ ${ }^{2}$ AgResearch Grasslands, Private Bag 11008, Palmerston North, New Zealand 4442 \\ katherine.tozer@agresearch.co.nz
}

\begin{abstract}
Steep, non-cultivable hill country below 1000 m comprises about $40 \%$ of New Zealand's land surface and is known as "hill country". It is used predominantly for mixed livestock farming, and makes a large contribution to the national economy. Recently there has been renewed interest by industry and government in germplasm introduction through pasture establishment to increase forage supply in these difficult environments. In this review, establishment is defined as development of a sown pasture species to a stage where it is able to reseed. The aim of this review was to determine the effect of key factors associated with pre-sowing management, sowing, and post-sowing management on establishment, including: site selection, herbicides, the role of litter, grazing management, burning, weed and pest control, fallow, fertiliser, species selection, seed quality, sowing time, sowing method, sowing rate, seed inoculation, coating and pelleting, natural reseeding and dissemination of seeds by animals. Over 120 studies were reviewed. A secondary aim was to highlight directions for future research.
\end{abstract}

Keywords: establishment success, sowing, pasture renewal, oversowing

\section{Key messages:}

- The amount and density of the resident vegetation at oversowing is one of the most critical factors influencing success of oversowing

- The variety of species and cultivars available enables selection of a seed mix tailored to site-specific conditions

- Future research needs include: strategies that reduce seedling desiccation during establishment, weed and pest control, establishment of forage herbs, legume establishment and reseeding, improving the evenness of distribution of aerially sown seed, and novel seed coating and pelleting techniques to enhance seed-soil contact.

\section{Introduction}

Steep, non-cultivable hill country below $1000 \mathrm{~m}$ comprises about $40 \%$ of New Zealand's land surface (Blaschke et al. 1992) and is known as "hill country".
It comprises large tracts of land in the North and South Islands, much of which is used for mixed livestock farming, and makes a large contribution to the national economy. Extensive research in hill country on germplasm introduction using seed occurred in the 1980s/early 1990s. Recently, there has been renewed interest by industry and government in germplasm introduction to increase forage supply in these environments (Bray et al. 2013).

Seedling establishment has been defined in various ways, for example, by Charlton (1977) and Chapman et al. (1985). In this review, establishment is defined as development of a sown pasture species to a stage where it is able to reseed (which usually occurs within the first 12-18 months), and the review is limited mainly to New Zealand literature.

Establishment, survival, and growth of forages in hill country are governed predominantly by temperature, moisture, soil fertility, and plant management (Lambert et al. 1985; Scott et al. 1985; McKenzie et al. 1999). Whilst much South Island country originally in tussock grassland can be farmed at a range of soil nutrient states, North Island hill country is best farmed in a moderate to high fertility state to exclude or minimise re-invasion by scrub species (Scott et al. 1985; Krause et al. 1988; Blaschke et al. 1992; Bergin et al. 1995).

Apart from initial pasture development involving the clearance of scrub or bush and subsequent oversowing, the key options for increasing farm productivity on hill country are subdivision, topdressing with fertiliser or lime, management of livestock to ensure efficient and sustainable utilisation of forage, and introduction of new germplasm (Suckling 1966; Allan et al. 1985; Scott et al. 1985). If subdivision, topdressing and utilisation are advanced to the stage where further gains are sought, introducing new germplasm offers potential benefits of enhanced annual or seasonal production of forage, higher nutritive value of forage, and greater tolerance to factors such as drought, grazing, trampling, pests, or low fertility (Lambert et al. 1985). There is also the potential value of new germplasm to exploit the many different micro-sites present in hill pastures, and to allow for situations where the material was not introduced earlier, or was introduced but did not persist perhaps because of inappropriate management.

Many grass, legume, and herb species have been 
evaluated in hill country, particularly legumes to supply biologically fixed nitrogen to existing or introduced non-leguminous species (Suckling 1966; Chapman \& Macfarlane 1985; Lambert et al. 1985; Scott et al. 1985). Methods for establishing species from seed on hill country largely depend on slope angle, accessibility and risk of erosion. On moderate to steep hill country e.g. $>25^{\circ}$ slope angle, ground-based machinery is not able to be used safely for sowing species, requiring that seed be applied aerially using airplane or helicopter, or on the ground by hand or portable broadcast spinner. Utilising livestock to 'cultivate' the seedbed and aid in increasing seed-soil contact, and herbicides to kill or suppress the existing vegetation, are usually integral parts of the establishment process (Suckling 1966; Lambert et al. 1985; Hampton et al. 1999).

Establishment of seedlings on non-cultivable hill country is typically low due to many factors, including an inhospitable micro-climate with extremes of temperatures and moisture deficits, competition with existing vegetation, herbivory, and other factors. This may result in low germination, low emergence and low seedling establishment. For example, 4 months after sowing, only $7.6 \%$ of aerially sown seed and $7.9 \%$ of hand-sown seed established at Ballantrae in southern Hawke's Bay (Charlton 1977). In another study, 12$20 \%$ of perennial ryegrass (Lolium perenne) and cocksfoot (Dactylis glomerata) seeds germinated, but of the seeds that germinated, only 14 to $27 \%$ of them survived to the end of the first 12 months, depending on the species and site location (Cullen 1969). In a review, Campbell (1992) stated that the establishment of aerially broadcast viable seed usually ranges from 1 to $27 \%$ with a mean of $8 \%$, which is much lower than establishment using conventional cultivation techniques. Further research is, therefore, required on methods that will result in increased establishment.

The following sections summarise and discuss the effect of key factors associated with pre-sowing management, sowing, and post-sowing management on establishment, including: site selection, herbicides, the role of litter, grazing management, burning, weed and pest control, fallow, fertiliser, species selection, seed quality, sowing time, sowing method, sowing rate, seed inoculation, coating and pelleting, natural reseeding and dissemination of seeds by animals. Directions for future research are highlighted.

\section{Pre-sowing management}

Site selection is influenced by climatic variables such as moisture, temperature and light, which all play critical roles in germination, seedling establishment and survival (Campbell \& Swain 1973). Germinating seeds and seedlings are particularly vulnerable to desiccation (McWilliam et al. 1970; Gillingham 1973; Gillingham
\& Bell 1977), requiring management strategies to reduce moisture deficits during this vulnerable period. The combination of lack of effective moisture due to greater runoff and the vulnerability of a germinating seed to desiccation, may explain why moisture deficits are implicated as the main cause of mortality during germination and early seedling development (Campbell \& Swain 1973; Campbell 1992). Steep hill country is also prone to greater runoff than flat or gently sloping land. North-facing slopes are typically hotter and drier than south-facing slopes; species must be chosen to suit these different environments. For example, potential evapotranspiration in March, June, September and December was greater on north- than south-facing slopes at Ballantrae in southern Hawke's Bay (Lambert \& Roberts 1976). On north-facing slopes at Whatawhata (North Island moist hill country), moisture content in the top soil $(0-7.5 \mathrm{~cm}$ depth) was below wilting point between January and March during a 3 year experiment (Gillingham 1973).

Herbicide is generally necessary for successful establishment of pasture species because other methods are unable to substantially reduce competition from the resident vegetation when oversowing. Campbell (1992) and Cullen (1971) concluded that the cover and density of the resident vegetation at oversowing was the most critical factor influencing success of oversowing - the greatest establishment occurs where the most weeds are killed for the longest period. Several herbicides have been investigated, including paraquat and diquat (e.g. Chapman et al. 1985; MacFarlane 1985), amitrole (e.g. Charlton \& Henderson 1985), dicamba (e.g. Charlton \& Henderson 1985), 2,2 DPA, 2,4-D (Dowling et al. 1971) and glyphosate (e.g. Chapman et al. 1985). MacFarlane (1985) found that herbicide impact was greater on the easy rather than steep slopes, possibly because of the greater effective land area of steep slopes when the steeper angle is taken into account. Another alternative hypothesis is that there is an interaction between the response of the plant to herbicide and climatic variables, such as soil moisture, which would vary according to slope. Note also that herbicide residual activity sometimes has detrimental effects on establishing seedlings (e.g. Baars et al. 1982) - timing of application is therefore critical.

Litter (dead matter) cover can assist germination by modifying the microclimate by reducing temperature extremes, increasing relative humidity and creating a soil surface that is more amenable for germination, as well as reducing seed predation (McWilliam \& Dowling 1970; Campbell \& Swain 1973; Baars et al. 1982). For example, Chapman \& Fletcher (1985) found that seedling mortality was greatest where resident vegetation had been suppressed the most; up to $20 \%$ of seedlings died within 3 weeks of appearance 
in glyphosate-treated plots. They attributed this to factors that are more marked in exposed situations e.g. excessive bare ground, and damage from wind and surface drying. However, litter cover needs to be balanced against its potential to reduce seed-soil contact. There is little literature from New Zealand hill country determining the optimal cover and density of litter for germination and seedling emergence and survival. Slug abundance may also be enhanced by litter (Campbell \& Swain 1973), but the effect of litter on predation by invertebrates other than slugs is poorly understood.

Hard grazing (e.g. to less than $2 \mathrm{~cm}$ in height) is used as an alternative to, or in conjunction with herbicide application to reduce competition from resident vegetation. In most cases, hard grazing is unable to reduce competition sufficiently to allow good establishment of broadcast seed (Chapman \& Fletcher 1985; Campbell 1992). When combined with other strategies, such as treading of seed to increase seedsoil contact and herbicide application, hard grazing is effective (Sithamparanathan et al. 1986). Coarse salt application increases grazing intensity in localised areas because livestock crave salt which is often lacking in South Island hill country soils (Gillespie et al. 2006; Anderson et al. 2008). This enables resident vegetation to be heavily grazed, reduces competition, increases seed-soil contact and increases establishment of oversown species. For example, establishment of broadcast plantain (Plantago lanceolata) was much greater from swards to which salt had been applied than from swards that did not receive salt application (6.5 vs 1.1 seedlings $/ \mathrm{m}^{2}$, (Gillespie et al. 2006)). Hard grazing alone may be a useful strategy in tussock grasslands, where consideration must be given to the preservation of indigenous species.

While burning has been used extensively in hill country to remove resident vegetation and reduce competition, little research was found on this subject. Burning enhances herbicide action by removing litter (Sievwright 1957). Conversely, it also stimulates emergence from the weed seed bank and dries out and hardens the soil surface, making it more difficult for seed burial and penetration by young roots that are vulnerable to desiccation (Maret \& Wilson 2005).

Fallow (cessation from grazing) can reduce tiller density through density dependent mortality, creating an open sward to assist in germination and establishment of oversown species. However, spring to autumn fallow can also enhance seed production of the resident vegetation, while a shorter fallow, applied up to seed development or after seed fall, can decrease tiller density while avoiding the negative impacts of seeding weedy species (Nie et al. 1997; Nie et al. 1999). A chemical fallow can also increase soil moisture and change the microclimate through litter creation, while effectively removing resident vegetation.

Nutrient cycling is particularly patchy and inefficient in hill country although non-limiting nutrients are required if new pasture species are to be introduced. A key to this is ensuring an efficient nitrogen cycle through developing a stable legume population (Levy 1970). Legume choice is therefore critical to successful pasture establishment in hill country.

\section{Species}

Pasture species commercially available vary in their adaptation to different hill country environments (Table 1). Legumes are difficult to establish by broadcasting because of epigeal germination in which the first leaves (cotyledons) are elevated above the ground as the juvenile stem (hypocotyl) elongates (Charlton 1977). This is in contrast to grasses which have hypogeal development where the cotyledon is not elevated and is less exposed to the elements. The different early seedling development patterns between grasses and legumes affect the ability of the radicle (precursor of primary root) to penetrate the soil surface - radicles of grasses penetrate the soil more rapidly during germination and are less prone to desiccation than those of legumes. For this reason litter can help reduce moisture deficits and increase germination of legumes in particular. In summer-dry North Canterbury, the presence of litter increased emergence by 4 -fold in comparison to emergence from bare ground; the authors considered litter was essential for seedling establishment (Janson \& White 1971). White clover (Trifolium repens) does not generally survive on dry, sunny, north-facing slopes; birdsfoot trefoil (Lotus corniculatus) or lucerne (Medicago sativa) may be better choices (Allan \& Chapman 1987). However, lucerne seedlings are particularly prone to moisture deficits while establishing, and broadcasting is a high risk strategy for their establishment (Janson $\&$ White 1971). This may limit the use of lucerne in uncultivable hill country unless methods can be found that reduce moisture stress on seedlings as they emerge and develop. Red clover (Trifolium pratense) is best adapted to moist, cool locations while Caucasian clover (Trifolium ambiguum) is more drought-tolerant but often has low establishment (Rhodes \& Clare 1983; Allan \& Keoghan 1994; Moorhead et al. 1994). Subterranean clover (Trifolium subterraneum) is well adapted to summer-dry hill country where competition (shading) is removed before sowing and the species allowed to flower and set seed before summer drought (Smetham 2003a). Lotus (Lotus pedunculatus) is well adapted to acid soils (Scott \& Mills 1980), which are prevalent at higher altitudes in New Zealand hill / high country. It also establishes well in low phosphate soils 
Table 1 Guide to suitability of common pasture species for New Zealand environments and key papers on the establishment of common pastures species in hill country. A scale of 1 to 5 is used, where $1=$ low and $5=$ high suitability (criteria and rankings adapted from page $\mathrm{C}-38$, Fleming 2003).

\begin{tabular}{lcll}
\hline Pasture species & $\begin{array}{c}\text { Moist } \\
\text { hill } \\
\text { country }\end{array}$ & $\begin{array}{c}\text { North } \\
\text { Island } \\
\text { dry hill } \\
\text { country }\end{array}$ & $\begin{array}{l}\text { South } \\
\text { Island } \\
\text { dry hill } \\
\text { or high } \\
\text { country }\end{array}$ \\
\hline
\end{tabular}

\section{Grasses}

Lolium perenne (perennial ryegrass)

3

2

1

Dactylis glomerata (cocksfoot)

5

5

Festuca arundinacea (tall fescue)

Bromus wildenowii (prairie grass)

B. stamineus (grazing brome)

B. inermis (smooth brome)

Phalaris aquatica (phalaris)

Phleum pratense (timothy)
4

(Falloon \& Charlton 1984; Chapman et al. 1985; Barker \& Zhang 1988; Wedderburn et al. 1989; Wedderburn et al. 1990; Wedderburn \& Pengelly 1991; Moloney et al. 1993; Wedderburn et al. 1996; Rolston et al. 2000; Kemp et al. 2005)

(Allan 1985; Barker et al. 1985; Chapman et al. 1985; Allan 1986; Chapman \& Campbell 1986; Allan \& Chapman 1987; Barker \& Zhang 1988; Scott et al. 1995; Kemp et al. 2005)

(Charlton et al. 1986; Barker et al. 1993; Moloney et al. 1993; Allan \& Keoghan 1994; Scott et al. 1995; Kemp et al. 2005)

1 (Sithamparanathan et al. 1986; Hume \& Barker 1991; Moloney et al. 1993; Scott et al. 1995; Stewart 1996b)

3 (Sithamparanathan 1979; Stewart 1996b)

5 (Woodman et al. 1992; Scott et al. 1995)

2 (Barker et al. 1988; Stevens et al. 1988; Moloney et al. 1993; Oram et al. 2009)

$5 \quad$ (Lambert 1954; Charlton et al. 1986;

Allan \& Chapman 1987; Charlton \& Stewart 2000; Moot et al. 2000)

\section{Legumes}

Trifolium repens (white clover)

T. pratense (red clover)

T. ambiguum (Caucasian clover)

L. corniculatus (birdsfoot trefoil)

Trifolium hybridum (alsike clover)

Hedysarum coronarium (sulla)

\section{Herbs}

Cichorium intybus (chicory)

Plantago lanceolata (plantain)
2

2

3
1

2

4

4

3

4

1

1

2
(Chapman et al. 1985; Chapman \& Fletcher 1985; MacFarlane \& Bonish 1986; Chapman et al. 1993; Hume \& Chapman 1993)

(Musgrave 1976b; Charlton 1977; Rhodes \& Clare 1983; Allan \& Chapman 1987; Scott \& Covacevich 1987)

(Lucas et al. 1980; Daly \& Mason 1987; Allan \& Keoghan 1994; Moorhead et al. 1994; Pryor et al. 1996; Scott 1998)

(Charlton 1977; White \& Meijer 1978; Chapman et al. 1986; MacFarlane et al. 1989; Smetham 2003b; Grigg et al. 2008)

(Janson \& White 1971; Campbell 1974; Musgrave et al. 1974; Musgrave 1976a; Baars et al. 1982; Musgrave 1983; McGowan et al. 2003)

(Charlton \& Brock 1980; Lucas et al. 1980; Scott \& Mills 1980; Sheath 1980; Wedderburn \& Lowther 1985)

(Chapman et al. 1990; Woodman et al. 1992; Fraser et al. 1994; Ayres et al. 2006)

(White \& Meijer 1978; Floate et al. 1985; Allan \& Chapman 1987; Woodman et al. 1992)

(Watson 1982; Niezen et al. 2002)

(Korte \& Rhodes 1993; Milne et al. 1993; Sanderson \& Elwinger 2000; Li \& Kemp 2005)

(Stewart 1996a; Dodd et al. 2000; Sanderson \& Elwinger 2000; Gillespie et al. 2006) 
while showing a strong growth response to nutrient application (Scott \& Mills 1980).

Establishment of grasses is limited by seed and seedling predation, moisture deficits and competition. There may also be interactions between new versus older germplasm and other factors relevant to establishment (e.g. drought tolerance, insect predation). Perennial ryegrass germinates rapidly and is easy to establish in comparison to many other grass species (e.g. Charlton et al. 1986). While cocksfoot is persistent, cocksfoot and tall fescue (Festuca arundinacea) are slower to establish but are more drought tolerant than perennial ryegrass (Chapman et al. 1985; Meurk \& Turner 1985). Both cocksfoot and tall fescue are unlikely to maintain their presence in a pasture through natural self-seeding and seedling recruitment (Hume \& Barker 1991). There are numerous Bromus species with different environmental tolerances. Of these, prairie grass has been used most widely, and is best established in spring (Sithamparanathan et al. 1986). Phalaris (Phalaris aquatica) is also drought tolerant and can spread by rhizomes but has potential production of toxic alkaloids and it may not be as well adapted to surface sowing as perennial ryegrass and cocksfoot (Campbell 1968; Stevens et al. 1988). Negligible literature was found on establishment of timothy (Phleum pratense) in hill country and given its preference for cool and moist environments it is not recommended for summer-dry hill country (Charlton \& Stewart 2000).

Little information is available on the establishment of chicory (Cichorium intybus) and plantain in hill country. While both are drought tolerant, plantain appears to be more promising in drought prone country as it is more persistent than chicory. Both species have epigeal germination and may therefore benefit from the presence of litter.

More recently, a summer crop, sometimes sown with forage herbs and clovers, has been used during the renewal process (Lane et al. 2016). A summer crop provides high quality forage and an opportunity for weed control before sowing the pasture mix.

\section{Sowing}

Seed quality, of which germination percentage is a key measure, can be used to adjust sowing rates as was demonstrated in studies on white clover, subterranean clover, strawberry clover (Trifolium fragiferum), lotus, perennial ryegrass and cocksfoot (e.g. Charlton \& Giddens 1983). Interspecific variability in seed germination, even within the same trial, emphasises the importance of routine seed testing.

Sowing date is critical; in the South Island, the best time to oversow varies from early August on low sunny faces to late September on higher shady faces (Allan et al. 1985). In North Island summer-dry hill country, oversowing in autumn is considerably more successful than in spring, whereas in summer-moist country, oversowing in spring is more successful than oversowing in autumn (Lambert et al. 1985). The likely environmental conditions for the first few months following oversowing are important when deciding sowing time. For example, germination of lotus 'Grasslands Maku' is low at low temperatures (e.g. $5^{\circ} \mathrm{C}$, Charlton 1989) and is better sown in early autumn or in mid- to late spring, when soil temperatures are higher. In contrast, red clover and white clover are less temperature dependent and their germination will generally be higher than that of lotus if sown in late autumn or early spring (Hampton et al. 1986). There are also differences between grass species; perennial ryegrass germination is less sensitive to temperature than that of timothy, phalaris, prairie grass (B. wildenowii), cocksfoot and tall fescue. Therefore perennial ryegrass is likely to have higher germination than these species in late autumn when soil temperatures are lower.

A large range of seed mixtures are sown, from single species of grass or legume, through to grasslegume mixtures comprising up to ten species. Limited research has been conducted on the establishment and ecological merits of oversowing grasses and legumes together versus oversowing legumes first and grasses later (e.g. White et al. 1972). If grasses are introduced later, then strategies to manage the existing vegetation comprising the new legume germplasm, are poorly defined. Sometimes, seed is sown with fertiliser but in the literature, responses depend on the existing soil fertility status, fertiliser type and rate, time of application, and species sown. Legumes often respond to increasing rates of phosphate whereas application of this nutrient mostly has negligible or no effect on grass establishment (e.g. Cullen et al. 1966; Lucas et al. 1980).

Pests consume seeds and defoliate germinating seedlings (e.g. slugs, caterpillars, field crickets, birds) and have accounted for the loss of up to $5 \%$ of the seed sown (Barker \& Zhang 1988).

While many New Zealand soils now contain effective Rhizobium strains that can nodulate white clover, red clover and alsike clover (Trifolium hybridum) (Andrews et al. 2015), inoculation may be required on new pastoral land that has been cleared directly from scrub or pastoral land where there is no evidence of resident clover (Lowther \& Kerr 2011). It is essential to inoculate seed of legumes new to an area and best to sow immediately after inoculation to minimise storage time and enhance rhizobia survival. Lime pelleting and high inoculation rates enhance establishment under favourable conditions following oversowing, but results are less satisfactory under adverse conditions such as hot, dry conditions (White 1973). Using coated 
grass seed can result in large increases in establishment by improving germination, possibly through altered moisture patterns, although results are highly variable (Allan et al. 1985).

Technology is available to apply a range of microbes to the surface of seeds that can provide control of insect pests and diseases, improve nutrient uptake, or promote growth (Bashan 1998). However, this requires more than just a microbial coating. Using a formulation science approach (McQuilken et al. 1998), other physical components and chemical amendments can be incorporated in successive layers around the seed. Also, there are alternatives to traditional aerial delivery of seeds, such as hydroseeding or dispersal after ingestion by sheep or cattle (Aird 2008). Protection from digestion could also be included in future seed coat design. Clever seed coats can be developed to utilise a range of properties such as insect pest control, fungal pathogen control, seedling inoculation and growth enhancement, and increased availability of nutrients, to achieve a step-change in seed establishment in challenging hill country environments.

\section{Post-sowing management}

Trampling areas immediately after oversowing with high stock densities for short durations (mostly hours) increases seed-soil contact. No literature could be found on the effectiveness of this practice on factors such as depth of seed burial. Sheep are used most often (e.g. 1 700 ewes/ha for 2-5 hours), and less frequently, cattle (e.g. Barker et al. 1988; Hume \& Chapman 1993).

Little research has been conducted on pest control. Application of parathion reduced seedling losses of white clover and lotus from $19 \%$ to $1 \%$ eight weeks after sowing (Barratt \& Johnstone 1984) and in the North Island, it was found that adult porina and grass grub were less likely to lay their eggs in short than long pasture (Suckling 1966).

Fertiliser, mainly superphosphate, was added within one year after species introduction in a few studies in the North Island but the benefits of application were uncertain within the seedling establishment period (Suckling 1950).

Regrowth of resident vegetation is a major challenge to seedling establishment (e.g. Suckling 1966). Grazing management can assist in management of this and time of first grazing after sowing will depend on location, botanical composition of the existing sward, and introduced species, e.g. grasses vs legumes. Spelling grass seedlings for 6-8 weeks may enable them to develop strong root systems before grazing (Suckling 1966). Both set stocking and rotational or intermittent grazing may be appropriate options for at least the first 12 months after sowing (e.g. Cullen 1971; Sheely \& Pringle 1979). Reproductive growth of grasses during summer and autumn sometimes makes grazing difficult because of the relatively unpalatable herbage, which requires longer periods of stock grazing to achieve acceptable utilisation (Suckling 1959). It appears that no research has been conducted on the efficacy of using herbicides to control regrowth of the resident pasture after sowing.

\section{Other techniques for establishing species}

Natural reseeding of legume species was investigated in the lower North Island in the 1950s/1960s, focusing on the potential to increase quantity of buried seed (Suckling 1951; Suckling 1966). Reseeding of white clover, red clover and lotus is negligible under close continuous grazing whereas reseeding of subterranean clover can still occur (Suckling 1951). With an initial nucleus of plants of Trifolium spp. established from oversowing, it is possible to thicken a stand by spelling over the summer. Length of spelling for best results varies with species, ranging from 6 weeks for white clover to 3 months for red clover and lotus (Suckling 1951). There is a lack of recent research on natural reseeding of legumes in New Zealand hill country.

Reseeding in tall fescue, phalaris and cocksfoot is negligible while that of perennial ryegrass and prairie grass is greater (Hume \& Barker 1991). Prairie grass presence, in particular, depends on natural reseeding. No information was available on the reseeding of herbs. Livestock may also introduce and disseminate legume seed. In one study, cow dung contained 7788 legume seeds per kg, equivalent to $11.9 \mathrm{~kg} / \mathrm{ha}$ (Suckling 1951). When ingested and passed through sheep, hard seed of white clover has a higher survival rate than nonhard seed (Suckling 1952). Grazing sheep on areas of white clover with ripe seed, or on seed crops, and then transferring them to clover-deficient hill country, could be potentially useful approaches. Another option is feeding hay with high seed content, and likely high hard seed content (Suckling 1966). Modern seed coating technologies could be used to protect ingested seed for subsequent dispersal by grazing animals.

\section{Future research directions}

Given the importance of hill country in New Zealand for agricultural production and the current environmental challenges it faces (Anon 2015), further research is required that results in economically and environmentally sustainable management practices. While much has been done, gaps remain. Based on this review, key gaps include:

- Pre-sowing management: strategies to reduce seedling desiccation during the establishment phase (including the potential for seed coating materials to increase water retention and seedling survival), 
optimal herbicide application rates and weed control during establishment, the impacts of chemical fallows and litter on subsequent establishment, annual legume management to ensure reseeding, and forage herb establishment.

- Sowing management: sowing sequence strategies to enhance legume establishment, novel strategies to increase seed-soil contact (including novel seed coating / pelleting techniques), rhizobia management, pest control, strategies to improve seed dissemination (including coatings to enhance establishment success and the role of grazing livestock), and strategies that improve aerial application and a more even distribution of seed.

- Post-sowing management: efficacious herbicide use for weed control.

Continuing collaboration between research agencies, industry bodies, regional councils and innovative farmers will ensure that the most relevant research programmes on pasture establishment are conducted to provide national benefit for hill country livestock enterprises and the rural communities they support.

\section{ACKNOWLEDGEMENTS}

P21 programme, Beef + Lamb New Zealand and Jenni Barr for assistance with obtaining references.

\section{REFERENCES}

Aird, J. 2008. Hydroseeding tips and techniques from the pros. Erosion Control 15: 30-33.

Allan, B.E. 1985. Grazing effects on pasture and animal production from oversown tussock grassland. Proceedings of the New Zealand Grassland Association 46: 119-125.

Allan, B.E. 1986. Pasture species most suited to nonarable hill and high country: a new look at traditional species. pp. 39-44. In: Proceedings of the 1985 hill and high country seminar. Centre for Resource Management, Lincoln College.

Allan, B.E.; Chapman, H.M. 1987. Oversown tussock country: lessons from 30 years of improvement and management on Tara Hills. Proceedings of the New Zealand Grassland Association 48: 77-81.

Allan, B.E.; Keoghan, J.M. 1994. More persistent legumes and grasses for oversown tussock country. Proceedings of the New Zealand Grassland Association 56: 143-147.

Allan, B.E.; Lowther, W.L.; Walton, P.J. 1985. Planning, establishment and management of pastures in the high country. Using herbage cultivars. Grasslands Research and Practice Series 3: 17-20.

Anderson, P.; Hawke, M.F.; Hobson, B.; Lucas, R.J.; O'Connor, M.; Whittaker, S. 2008. Use of salt in New Zealand pastoral farming. Domain Salt Ltd., Mount Maunganui South, New Zealand, 11 pp.
Andrews, M.; Jack, D.; Dash, D.; Brown, S. 2015. Which rhizobia nodulate which legumes in New Zealand soils? Journal of New Zealand Grasslands 77: 281-286.

Anon 2015. New Zealand's Environmental Reporting Series: Environment Aotearoa 2015. Ministry for the Environment \& Statistics, New Zealand.

Ayres, J.F.; Blumenthal, M.J.; Lane, L.A.; O'Connor, J.W. 2006. Birdsfoot trefoil (Lotus corniculatus) and greater lotus (Lotus uliginosus) in perennial pastures in eastern Australia. 2. Adaptation and applications of lotus-based pasture. Australian Journal of Experimental Agriculture 46: 521-534.

Baars, J.A.; Douglas, J.A.; Allan, P.J.T. 1982. Lucerne (Medicago sativa L.) establishment on uncultivated pumice hill country (North Island). New Zealand Journal of Experimental Agriculture 10: 31-36.

Barker, D.J.; Chapman, D.F.; Anderson, C.B.; Dymock, N. 1988. Oversowing 'Grasslands Wana' cocksfoot, 'Grasslands Maru' phalaris, and 'Grasslands Tahora' white clover in hill country at varying rates of paraquat and glyphosate. New Zealand Journal of Agricultural Research 31: 373-382.

Barker, D.J.; Lancashire, J.A.; Meurk, C. 1985. 'Grasslands Wana' cocksfoot- an improved grass suitable for hill country. Proceedings of the New Zealand Grassland Association 46: 167-172.

Barker, D.J.; Lancashire, J.A.; Moloney, S.C.; Dymock, N.; Stevens, D.R.; Turner, J.D.; Scott, D.; Archie, W.J. 1993. Introduction, production, and persistence of five grass species in dry hill country: 8 . Summary and conclusions. New Zealand Journal of Agricultural Research 36: 61-66.

Barker, D.J.; Zhang, D.M. 1988. The effects of paraquat spraying, seed placement and pre-germination on the appearance and survival of white clover, cocksfoot and ryegrass seedlings from spring oversowing in hill country. New Zealand Journal of Experimental Agriculture 16: 1-9.

Barratt, B.I.P.; Johnstone, P.D. 1984. Effects of insects, seeding rate, and insecticide seed dressing on white clover and Maku lotus in tussock grassland. New Zealand Journal of Agricultural Research 27: 13-18.

Bashan, Y. 1998. Inoculants of plant growth-promoting bacteria for use in agriculture. Biotechnology Advances 16: 729-770.

Bergin, D.O.; Kimberley, M.O.; Marden, M. 1995. Protecting value of regenerating tea tree stands on erosion-prone hill country, East Coast, North Island, New Zealand. New Zealand Journal of Forestry Science 25: 3-19.

Blaschke, P.M.; Trustrum, N.A.; DeRose, R.C. 1992. Ecosystem processes and sustainable land use in New Zealand steeplands. Agriculture, Ecosystems and Environment 41: 153-178. 
Bray, A.R.; Fraser, T.J.; King, W.M.; Mackay, A.D.; Moot, D.J.; Stevens, D.R. 2013. Pasture improvement needs and options for New Zealand sheep and beef farms. pp. 844-845. In: Proceedings of the 22nd International Grassland Congress. Eds. Michalk, D. L.; Millar, G. D.; Badgery, W. B.; Broadfoot, K. M. New South Wales Department of Primary Industry, Sydney, Australia.

Campbell, B.D. 1992. Extending the frontiers of aerially sown pastures in temperate Australia: a review. Australian Journal of Experimental Agriculture 32: 127-148.

Campbell, M.H. 1968. Establishment, growth and survival of six pasture species surface sown on unploughed land infested with serrated tussock (Nassella trichotoma). Australian Journal of Experimental Agriculture and Animal Husbandry 8: 557-560.

Campbell, M.H. 1974. Establishment, persistence and production of lucerne-perennial grass pastures surface-sown on hill country. Australian Journal of Experimental Agriculture and Animal Husbandry 14: 507-514.

Campbell, M.H.; Swain, F.G. 1973. Factors causing losses during the establishment of surface-sown pastures. Journal of Range Management 26: 355359.

Chapman, D.F.; Campbell, B.D. 1986. Establishment of ryegrass, cocksfoot, and white clover by oversowing in hill country. 2. Sown species and total herbage accumulation. New Zealand Journal of Agricultural Research 29: 33-37.

Chapman, D.F.; Campbell, B.D.; Harris, P.S. 1985. Establishment of ryegrass, cocksfoot, and white clover by oversowing in hill country. 1. Seedling survival and development, and fate of sown seed. New Zealand Journal of Agricultural Research 28: 177-189.

Chapman, D.F.; Fletcher, R.H. 1985. Seedling appearance, survival, and development of 'Grasslands Huia', 'Grasslands Tahora', and Kent wild white clover cultivars after surface sowings in summer-moist hill country. New Zealand Journal of Agricultural Research 28: 191-199.

Chapman, D.F.; Macfarlane, M.J. 1985. Pasture growth limitations in hill country and choice of species. Using herbage cultivars. Grasslands Research and Practice Series 3: 25-29.

Chapman, D.F.; Mackay, A.D.; Devantier, B.P.; Dymock, N.; Anderson, C.B. 1993. Effects of cultivar introduction and fertilizer on characteristics of white clover (Trifolium repens L.) plants and populations in a hill pasture. New Zealand Journal of Agricultural Research 36: 87-98.

Chapman, D.F.; Sheath, G.W.; MacFarlane, M.J.;
Rumball, P.J.; Cooper, B.M.; Crouchley, G.; Hoglund, J.H.; Widdup, K.H. 1986. Performance of subterranean and white clover varieties in dry hill country. Proceedings of the New Zealand Grassland Association 47: 53-62.

Chapman, H.M.; Lowther, W.L.; Trainor, K.D. 1990. Some factors limiting the success of Lotus corniculatus in hill and high country. Proceedings of the New Zealand Grassland Association 51: 147150.

Charlton, J.F.L. 1977. Establishment of pasture legumes in North Island hill country. Part 2 Seedling establishment and plant survival. New Zealand Journal of Experimental Agriculture 5: 385-390.

Charlton, J.F.L. 1989. Temperature effects on germination of 'Grasslands Maku' lotus and other experimental lotus sections. Proceedings of the New Zealand Grassland Association 50: 197-201.

Charlton, J.F.L.; Brock, J.L. 1980. Establishment of Lotus pedunculatus and Trifolium repens in newly developed hill country. New Zealand Journal of Experimental Agriculture 8: 243-248.

Charlton, J.F.L.; Giddens, N.G. 1983. Establishment of hill country white clover selections from oversowing. Proceedings of the New Zealand Grassland Association 44: 149-155.

Charlton, J.F.L.; Hampton, J.G.; Scott, D.J. 1986. Temperature effects on germination of New Zealand herbage grasses. Proceedings of the New Zealand Grassland Association 47: 165-172.

Charlton, J.F.L.; Henderson, J.D. 1985. Techniques for establishing grass and clover in existing hill country pastures for evaluation purposes. New Zealand Journal of Experimental Agriculture 13: 111-116.

Charlton, J.F.L.; Stewart, A.V. 2000. Timothy - the plant and its use on New Zealand farms. Proceedings of the 34th New Zealand Weed and Pest Control Conference 62: 147-153.

Cullen, N.A. 1969. Oversowing grasses and clovers. Proceedings of the New Zealand Grassland Association 31: 110-116.

Cullen, N.A. 1971. Factors influencing establishment of oversown grasses and clovers on unploughable hill country. Research report No. 1. Invermay Agricultural Research Centre, Mosgiel, New Zealand. $32 \mathrm{pp}$.

Cullen, N.A.; McNaught, K.J.; Mountier, N.S. 1966. The establishment of pasture on yellow-brown loams near Te Anau IV. The effect of lime and phosphate on establishment of clover and grass oversown on uncultivated ground. New Zealand Journal of Agricultural Research 9: 375-387.

Daly, G.T.; Mason, C.R. 1987. Performance of Caucasian and zigzag clovers. Proceedings of the New Zealand Grassland Association 48: 151-156. 
Dodd, M.B.; Barker, D.J.; Dymock, N.; Orr, S.J. 2000. Factors influencing the contribution of narrow-leaved plantain to North Island hill country pastures. Proceedings of the New Zealand Grassland Association 62: 179-182.

Dowling, P.M.; Clements, R.J.; McWilliam, J.R. 1971. Establishment and survival of pasture species from seed sown on the soil surface. Australian Journal of Agricultural Research 22: 61-74.

Falloon, R.E.; Charlton, J.F.L. 1984. Establishment of oversown perennial ryegrass in North Island hill country. Proceedings of the New Zealand Grassland Association 45: 219-224.

Fleming, P.H. 2003. Farm Technical Manual. Farm Management Group, Lincoln University, Lincoln, New Zealand, 400 pp.

Floate, M.J.S.; McIntosh, P.D.; Risk, W.H.; P.D. Enright, P.D.; Smith, L.C. 1985. Effects of fertilisers and environment on lotus production on high country acid soils in Otago. Proceedings of the New Zealand Grassland Association 46: 111-118.

Fraser, W.J.; Ogden, S.C.; Woodman, R.F.; Lowther, W.L. 1994. Role of re-seeding and seedling recruitment for sustainable Lotus corniculatus based pastures in dry hill and high country. Proceedings of the New Zealand Grassland Association 56: 139-142.

Gillespie, B.J.; Lucas, R.J.; Moot , D.J.; Edwards, G.R. 2006. Can topdressing with salt increase oversowing success and pasture quality on steep, south facing slopes in hill country pastures? Proceedings of the New Zealand Grassland Association 68: 349-353.

Gillingham, A.G. 1973. Influence of physical factors on pasture growth on hill country. Proceedings of the New Zealand Grassland Association 35: 77-85.

Gillingham, A.G.; Bell, L.D. 1977. Effect of aspect and cloudiness on grass and soil temperatures at a hill site in Raglan County. New Zealand Journal of Agricultural. Research 20: 37-44.

Grigg, D.W.; Grigg, J.M.; Lucas, R.J. 2008. Maximising subterranean clover in Marlborough's hill country is key to weaning $80 \%$ of sale lambs prime. Proceedings of the New Zealand Grassland Association 70: 25-29.

Hampton, J.G.; Charlton, J.F.L.; Bell, D.D.; Scott, D.J. 1986. Temperature effects on the germination of herbage legumes in New Zealand. Proceedings of the New Zealand Grassland Association 48: 177-183.

Hampton, J.G.; Kemp, P.D.; White, J.G.H. 1999. Pasture establishment. pp. 101-115. In: New Zealand pasture and crop science. Eds. White, J.; Hodgson, J. Oxford University Press, Melbourne, Australia.

Hume, D.E.; Barker, D.J. 1991. Natural reseeding of five grass species in summer dry hill country. Proceedings of the New Zealand Grassland Association 53: 97-104.
Hume, D.E.; Chapman, D.F. 1993. Oversowing of five grass species and white clover on a Taupo hill country pumice soil. New Zealand Journal of Agricultural Research 36: 309-322.

Janson, C.G.; White, J.G.H. 1971. Lucerne establishment studies on uncultivatable country. I. Germination and seedling establishment. New Zealand Journal of Agricultural Research 14: 572586.

Kemp, P.D.; Matthew, C.; Lucas, R.J. 2005. Pasture species and cultivars. pp. 83-101. In: New Zealand pasture and crop science. Eds. White, J.; Hodgson, J. Oxford University Press, Melbourne, Australia.

Korte, C.J.; Rhodes, A.P. 1993. Economics of droughttolerant pastures for cattle finishing on Hawkes Bay and Wairarapa hill country farms. Proceedings of the New Zealand Grassland Association 55: 45-49.

Krause, M.A.; Beck, A.C.; Dent, J.B. 1988. Control of gorse in hill country: An economic assessment of chemical and biological methods. Agricultural Systems 26: 35-49.

Lambert, J.P. 1954. Value of pasture species in Otago and Southland. Proceedings of the New Zealand Grassland Association 16: 122-131.

Lambert, M.G.; Rhodes, A.P.; Barker, D.J.; Bircham, J.S. 1985. Establishing and managing improved plants in hill country. Using herbage cultivars. Grassland Research and Practice Series 3: 31-35.

Lambert, M.G.; Roberts, E. 1976. Aspect differences in an unimproved hill country pasture. I. Climatic differences. New Zealand Journal of Agricultural Research 19: 459-467.

Lane, P.M.S.; Lee, S.C.; Willoughby, B. 2016. Hill country cropping with no land based equipement. Grassland Research and Practice Series 16: 251256.

Levy, E.B. 1970. Grasslands of New Zealand. Government printer, Wellington, New Zealand. 374 pp.

Li, G.; Kemp, P.D. 2005. Forage chicory (Cichorium intybus L.): a review of its agronomy and animal production. Advances in Agronomy 88: 187-222.

Lowther, W.L.; Kerr, G.A. 2011. White clover seed inoculation and coating in New Zealand. Proceedings of the New Zealand Grassland Association 73: 93102.

Lucas, R.J.; White, J.G.H.; Daly, G.T.; Jarvis, P.; Meijer, G. 1980. Lotus, white clover and Caucasian clover oversowing, Mesopotamia station, South Canterbury. Proceedings of the New Zealand Grassland Association 42: 142-151.

MacFarlane, M.J. 1985. Paraquat at low water rates for sward suppression during oversowing into unimproved pastures. Proceedings of the 38th New Zealand Weed and Pest Control Conference. 110-114. 
MacFarlane, M.J.; Bonish, P.M. 1986. Oversowing white clover into cleared and unimproved North Island hill country - the role of management, fertiliser, inoculation, pelleting and resident rhizobia. Proceedings of the New Zealand Grassland Association 47: 43-51.

MacFarlane, M.J.; McGowan, A.W.; Sheath, G.W.; Korte, C.J. 1989. An on-farm evaluation of white and subterranean clovers in North Island hill country. Proceedings of the New Zealand Grassland Association 51: 157-162.

Maret, M.P.; Wilson, M.V. 2005. Fire and litter effects on seedling establishment in Western Oregon upland prairies. Restoration Ecology 13: 562-568.

McGowan, A.W.; Sheath, G.W.; Webby, R.W. 2003. Lucerne for high quality summer feed in North Island hill country. Legumes for dryland pastures. Grassland Research and Practice Series 11: 169174.

McKenzie, B.A.; Kemp, P.D.; Moot , D.J.; Matthew, C.; Lucas, R.J. 1999. Environmental effects on plant growth and development. Chapter 3. pp. 29-44. In: New Zealand pasture and crop science. Eds. White, J.; Hodgson, J. Oxford University Press, Melbourne, Australia.

McQuilken, M.P.; Halmer, P.; Rhodes, D.J. 1998. Application of microorganisms to seeds. p. 412. In: Formulation of microbial biopesticides: beneficial microorganisms, nematodes, and seed treatments. Ed. Burges, H. D. Kluwer Academic Publishers, Dordrecht, Boston.

McWilliam, J.R.; Clements, R.J.; Dowling, P.M. 1970. Some factors influencing the germination and early seedling development of pasture plants. Australian Journal of Agricultural Research 21: 19-32.

McWilliam, J.R.; Dowling, P.M. 1970. Factors affecting the germination and establishment of pasture seed on the soil surface. pp. 578-583. In: Proceedings of the XI International Grasslands Congress. Ed. Norman, M. J. T. St Lucia: University of Queensland Press, Harlington, Queensland, Surfers Paradise, Australia.

Meurk, C.D.; Turner, J.D. 1985. Oversown grasses and their management on Southland hill country. Proceedings of the New Zealand Grassland Association 46: 199-202.

Milne, G.D.; Moloney, S.; Smith, D.R. 1993. Demonstration of dryland species on 90 east coast North Island farms. Proceedings of the New Zealand Grassland Association 55: 39-44.

Moloney, S.C.; Lancashire, J.A.; Barker, D.J. 1993. Introduction, production, and persistence of five grass species in dry hill country: 7. Central Plateau, North Island, New Zealand. New Zealand Journal of Agricultural Research 36: 49-59.
Moorhead, A.J.E.; White, J.G.H.; Jarvis, P.; Lucas, R.J.; Sedcole, J.R. 1994. Effect of sowing method and fertiliser application on establishment and first season growth of Caucasian clover. Proceedings of the New Zealand Grassland Association 56: 91-95.

Moot, D.J.; Scott, W.R.; Roy, A.M.; Nicholls, A.C. 2000. Base temperature and thermal time requirements for germination and emergence of temperate pasture species. New Zealand Journal of Agricultural Research 43: 15-25.

Musgrave, D.J. 1976a. Effect of ground cover and herbicide application on establishment of oversown lucerne. New Zealand Journal of Experimental Agriculture 4: 447-449.

Musgrave, D.J. 1976b. An evaluation of various legumes at high altitude. Proceedings of the New Zealand Grassland Association 38: 126-132.

Musgrave, D.J. 1983. Place of oversown lucerne in dry hill country farming systems. Proceedings of the New Zealand Grassland Association 44: 127-134.

Musgrave, D.J.; Clare, R.J.; Lowther, W.L. 1974. The potential for oversowing; lucerne on steepland soils in North and central Otago. Proceedings of the New Zealand Grassland Association 36: 89-96.

Nie, Z.N.; Barker, D.J.; Valentine, I.; Mackay, A.D.; Hodgson, J. 1999. Changes in the population of germinated seed in a hill pasture during and after a pastoral fallow. Grass and Forage Science 54: 127136.

Nie, Z.N.; Mackay, A.D.; Barker, D.J.; Valentine, I.; Hodgson, J. 1997. Changes in plant population density, composition and sward structure of a hill pasture during a pastoral fallow. Grass and Forage Science 52: 190-198.

Niezen, J.H.; Waghorn, G.C.; Graham, T.; Carter, J.L.; Leathwick, D.M. 2002. The effect of diet fed to lambs on subsequent development of Trichostrongylus colubriformis larvae in vitro and on pasture. Veterinary Parasitology 105: 269-283.

Oram, R.N.; Ferreira, V.; Culvenor, R.A.; Hopkins, A.A.; Stewart, A. 2009. The first century of Phalaris aquatica L. cultivation and genetic improvement: a review. Crop and Pasture Science 60: 1-15.

Pryor, H.N.; Lowther, W.L.; Trainor, K.D. 1996. Natural reseeding of Caucasian clover (Trifolium ambiguum) in tussock grasslands. Proceedings of the New Zealand Grassland Association 58: 171-175.

Rhodes, P.J.; Clare, R.J. 1983. Legume oversowing on hill country in Marlborough. Proceedings of the New Zealand Grassland Association 44: 142-148.

Rolston, M.P.; Fletcher, L.; Fletcher, C.; Archie, W. 2000. The viability of perennial ryegrass seed and its endophyte in sheep faeces. pp. 405-408. In: Proceedings of the Grassland Conference: 4th International Neotyphodium/Grass Interactions 
Symposium. Eds. Paul, V. H.; Dapprich, P. D. Universität-Gesamthochschle Paderborn, Abteilung Soest, Fachbereich Agrarwirtschaft.

Sanderson, M.A.; Elwinger, G.F. 2000. Seedling development of chicory and plantain. Agronomy Journal 92: 69-74.

Scott, D. 1998. Sixteen years of Caucasian clover under contrasting managements. Proceedings of the New Zealand Grassland Association 60: 115-118.

Scott, D.; Covacevich, N. 1987. Effects of fertiliser and grazing on a pasture species mixture in high country. Proceedings of the New Zealand Grassland Association 48: 93-98.

Scott, D.; Keoghan, J.M.; Cossens, G.G.; Maunsell, L.A.; Floate, M.J.S.; Wills, B.J.; Douglas, G.B. 1985. Limitations to pasture production and choice of species. Using herbage cultivars. Grassland Research and Practice Series 3: 9-15.

Scott, D.; Maunsell, L.A.; Keoghan, J.M.; Allan, B.E.; Lowther, W.L.; Cossens, G.G. 1995. A guide to pastures and pasture species for the New Zealand high country. Grassland Research and Practice Series 4:1-41.

Scott, R.S.; Mills, E.G. 1980. Establishment and management of 'Grasslands Maku' lotus in acid, low-fertility tussock grasslands. Proceedings of the New Zealand Grassland Association 42: 131-141.

Sheath, G.W. 1980. Effects of season and defoliation on the growth habits of Lotus pedunculatus Cav. cv. 'Grasslands Maku'. New Zealand Journal of Agricultural Research 23: 191-200.

Sheely, P.J.; Pringle, D.R.S. 1979. Hoof and tooth cultivation as an aid to establishing new or improved grasses in hill country pastures. Report prepared for Grasslands, AgResearch, Palmerston North, New Zealand.

Sievwright, H.M. 1957. Aerial farming in the South Island. II. Some aspects of aerial topdressing and seeding in the tussock country from the Waitaki to the Rakaia rivers. Proceedings of Lincoln College Farmers Conference 7: 70-77.

Sithamparanathan, J. 1979. Seasonal growth patterns of herbage species on high rainfall hill country in northern North Island. 1. Temperate grasses. New Zealand Journal of Experimental Agriculture 7: $157-$ 162.

Sithamparanathan, J.; Macfarlane, M.J.; Richardson, S. 1986. Effect of treading, herbicides, seasons and seed coating on oversown grass and legume establishment in easy North Island hill country New Zealand. New Zealand Journal of Experimental Agriculture 14: 173-182.

Smetham, M.L. 2003a. A review of subterranean clover (Trifolium subterraneum L.): its ecology, and use as a pasture legume in Australasia. Advances in Agronomy 79: 303-350.
Smetham, M.L. 2003b. Subterranean clover (Trifolium subterraneum): its history and current and future research in New Zealand. Legumes for dryland pastures. Grassland Research and Practice Series 11: 61-72.

Stevens, D.R.; Turner, J.D.; Barker, D.J.; Moloney, S. 1988. 'Grasslands Maru' phalaris: productive and persistent in hill country. Proceedings of the New Zealand Grassland Association 50: 231-236.

Stewart, A.V. 1996a. Plantain (Plantago lanceolata) a potential pasture species. Proceedings of the New Zealand Grassland Association 58: 77-86.

Stewart, A.V. 1996b. Potential value of some Bromus species of the section Ceratochloa. New Zealand Journal of Agricultural Research 39: 611-618.

Suckling, F.E.T. 1950. Strike of oversown grass and clover seed on hill pastures. New Zealand Journal of Science and Technology Section A 32: 1-9.

Suckling, F.E.T. 1951. Results of recent experiments on surface sowing. Proceedings of the New Zealand Grassland Association 13: 119-126.

Suckling, F.E.T. 1952. Dissemination of white clover (Trifolium repens) by sheep. New Zealand Journal of Science and Technology 33: 64-77.

Suckling, F.E.T. 1959. Pasture management trials on unploughable hill country at Te Awa. 2. Results for 1951-1957. New Zealand Journal of Agricultural Research 2: 488-553.

Suckling, F.E.T. 1966. Hill pasture improvement: a guide to better use of the hills. Newton King Group of Companies, DSIR, Wanganui, New Zealand, 58 pp.

Watson, M.J. 1982. Hedysarum coronarium - a legume with potential for soil conservation and forage. New Zealand Agricultural Science 16: 189-193.

Wedderburn, M.; Pengelly, W. 1991. Resident ryegrass in hill country pastures. Proceedings of the New Zealand Grassland Association 53: 91-95.

Wedderburn, M.E.; Adam, K.D.; Greaves, L.A.; Carter, J.L. 1996. Effect of oversown ryegrass (Lolium perenne) and white clover (Trifolium repens) on the genetic structure of New Zealand hill pastures. New Zealand Journal of Agricultural Research 39: 41-52.

Wedderburn, M.E.; Lowther, W.L. 1985. Factors affecting establishment and spread of lotus in tussock grasslands. Proceedings of the New Zealand Grassland Association 46: 97-101.

Wedderburn, M.E.; Pengelly, W.J.; Tucker, M.A.; di Menna, M.E. 1989. Description of ryegrass removed from New Zealand North Island hill country. New Zealand Journal of Agricultural Research 32: 521-529.

Wedderburn, M.E.; Tucker, M.A.; Pengelly, W.J. 1990. Responses of a New Zealand North Island hill perennial ryegrass collection to nitrogen, moisture stress and grass grub (Costelytra zealandica) infestation. New Zealand Journal of Agricultural Research 33: 405-411. 
White, J.G.H. 1973. Improvement of hill country pastures. pp. 259-290. In: pasture and pasture plants. Ed. Langer, R. H. M. AH \& AW Reed, Wellington, New Zealand.

White, J.G.H.; Meijer, G. 1978. Legumes and grasses for dry North Canterbury hill country. Proceedings of the New Zealand Grassland Association 40: 170179.
White, J.G.H.; Meijer, G.; Langer, R.H.M. 1972. Oversowing grasses on sunny and shady faces. Proceedings of the New Zealand Grassland Association 34: 139-146.

Woodman, R.F.; Keoghan, J.M.; Allan, B.E. 1992. Pasture species for drought-prone lower slopes in the South Island high country. Proceedings of the New Zealand Grassland Association 54: 115-120. 